\title{
COMPARATIVE PHARMACOGNOSTICAL EVALUATION OF COSTUS SPECIOSUS (WILD GINGER) AND ZINGIBER OFFICINALE (GINGER) RHIZOME
}

\author{
CHANDRA KALA ${ }^{1}$, SYED SALMAN ALI ${ }^{2 *}$, SUDHIR CHAUDHARY ${ }^{3}$
}

${ }^{1}$ Glocal School of Pharmacy, The Glocal University, Delhi-Yamunotri Marg (State Highway 57), Mirzapur Pole, Saharanpur, Uttar Pradesh, India 247121, ${ }^{2}$ School of Pharmaceutical Sciences, IFTM University Lodhipur Rajput, Delhi Road NH-24, Moradabad, Uttar Pradesh 244102, ${ }^{3}$ Meerut Institute of Engineering and Technology, Department of Pharmaceutical Technology, NH-58, Baghpat Crossing, Bypass Road Meerut (250005), Uttar Pradesh, India

Email: chandrakala@theglocaluniversity.in

Received: 29 Jul 2016, Revised and Accepted: 06 Sep 2016

ABSTRACT

Objective: Costus speciosus Koen. (Ginger) is an Indian ornamental plant, belonging to family Costaceae. The present research work deals with the establishment of standardization parameter regarding comparative pharmacognostic study between Costus speciosus and Zingiber officinale rhizome.

Methods: Macroscopic and microscopic evaluation, physicochemical parameters like ash values, moisture content, extractive value, fluorescence analysis and the preliminary phytochemical investigation was done.

Results: The Macroscopic difference was found as an absence of odor and taste in Costus speciosus and presence of pungent and aromatic odor in Zingiber officinale. Oil globule, tracheids, starch granules in Zingiber officinale was found whereas the absence of the same in Costus speciosus rhizome was found in the microscopic evaluation. Fluorescence study also exhibits differences. The presence of saponin, carbohydrate, glycosides in Costus speciosus whereas Zingiber officinale revealed the presence of alkaloids, glycosides, flavonoids and protein.

Conclusion: These finding can serve as the basis for Identification and investigation of Costus speciosus and Zingiber officinale rhizome and can also establish the characteristic differentiating features of both.

Keywords: Costus speciosus, Zingiber officinale, Physiochemical parameters

(C) 2016 The Authors. Published by Innovare Academic Sciences Pvt Ltd. This is an open access article under the CC BY license (http://creativecommons.org/licenses/by/4.0/) DOI: http://dx.doi.org/10.22159/ijcpr.2016v8i4.15270

\section{INTRODUCTION}

Costus speciosus Koen. (Keu, Crape ginger), an Indian ornamental plant, belonging to family Costaceae. The plant is widely distributed in India in the tropical or sub-tropical climate from the sea level to the Himalayas, excluding the arid and semi-arid areas of Punjab, Haryana, Rajasthan, Gujarat and the peninsular India. It is found throughout the country in moist tropical evergreen forests, up to an altitude of $1200 \mathrm{~m}$. It is common along roadsides, streams and in wastelands. It is widely distributed in Assam, Meghalaya, Bihar, Khasi and Jaintia Hills, Uttaranchal, Orissa, MP, North Bengal [1]. The rhizomes are bitter and show anthelmintic, astringent, expectorant properties. The rhizome extract is used as a tonic and useful in relieving burning sensation, constipation, leprosy, asthma, bronchitis, anemia and other skin ailments, fever and has hepatoprotective properties. Rhizome paste is used for treating boils and also to make sexual hormones and contraceptive. Leaves are used for scabies and stomach ailments. Stems are ground into a paste and applied for blisters. Rhizome extract is used for treating snake bites. The rhizome is used internally in the treatment of abdominal pain, liver problems, jaundice, gall bladder pain, etc. The Leaves also possess hypoglycemic properties and insulin potentiating action in addition to decreasing blood glucose. The rhizome possesses antifertility, anticholinesterase, anti-inflammatory, antipyretic and antihelminthic activities. Pharmacological studies showed that the rhizomes of C. speciosus possess cardiotonic, hydrochloric, diuretic and CNS depressant activity [2-4]

Zingiber officinale was also one of the first oriental spices to be grown to the Europeans. But now it is found to grow extensively in the tropical and subtropical regions of the world particularly in Bangladesh, India, Taiwan, Jamaica, Africa, Mexico, China and Japan. It is a household remedy for dyspepsia, flatulence, colic and diarrhea1. Ginger rhizomes contain both aromatic and pungent compounds. It has been shown to have an antipyretic, hypotensive, cardiotonic, antiplatelet, antiangiogenic, anti-inflammatory and analgesic, cytotoxic, apoptotic and antitumor activities. Ginger oil is used primarily as food flavoring agent in soft drinks, like spices in bakery products, in confectionary items, pickles, sauces and as a preservatives, etc. It is used for treating nausea caused by sickness, morning sickness and chemotherapy $[5,6]$.

\section{MATERIALS AND METHODS}

\section{Plant material}

The semi-dried, the rhizome of the plant Costus speciosus was collected from the Karnal, in the month of September 2012, authenticated by VHCA herbals. The rhizome of Zingiber officinale was collected from local market of Meerut and authenticated by Dr. R. S. Saxena, Deptt. of Botany, Meerut college. The plant material was further size reduced and stored until further use in an air tight container. Fresh plant material was obtained for the microscopical evaluation of rhizome, and dried plant material was used for phytochemical screening and to estimate ash value, extractive values and fluorescence studies.

Chemicals

All the chemical were reagent grade and were purchased from $\mathrm{CDH}$, New Delhi.

\section{Pharmacognostic study}

The Rhizome of Costus speciosus and Zingiber officinale was extracted with $50 \%$ ethanol. The coarse powder of plant was placed in soxhlet apparatus at $65-70^{\circ} \mathrm{C}$ for $18 \mathrm{~h}$. After $18 \mathrm{~h}$ evaporate the extract at $80^{\circ} \mathrm{C}$.

\section{Macroscopic and microscopic analysis}

The pharmacognostical evaluation was carried out by free hand sectioning of the plant material. Histochemical studies were conducted using various reagents such as phloroglucinol and $\mathrm{HCl}$, Aniline blue, iodine and potassium iodide, lactophenol, ferric chloride, and FABIL (basic fuschin, aniline blue, iodine and 
potassium iodide in lactophenol) [7, 8]. Photomicrographs were obtained by observing free hand section of the drug under compound binocular microscope OLYMPUS BX41 and photomicrography was done using Olympus C7070 Camera.

\section{Physico-chemical analysis}

The coarse powder of rhizome of Costus speciosus and Zingiber officinale was subjected to various physicochemical studies for determination of ash value (total ash, acid insoluble and water soluble ash) extractive values (water soluble, alcohol soluble and petroleum ether soluble and chloroform-soluble), and fluorescence properties [10].

\section{Preliminary Phytochemical screening}

Qualitative estimation of hydroalcoholic extract of Costus speciosus and Zingiber officinale were performed for the identification of various chemical constituents like alkaloid, carbohydrate, flavonoids, proteins, amino acids, phenols, tannins, glycosides and steroids [11].

\section{RESULTS}

\section{Macroscopic character}

\section{Costus speciosus}

Perennial herb with an erect stem about $3 \mathrm{~m}$ tall. Leaves are dark green, smooth, alternate, elliptic in shape and spirally arranged around the unbranched stem which itself is twisted at the upper part. The inflorescence is the spike with ovate, red bracts. Flowers are large and white in color. The rhizome is usually buff colored, tuberous, curved or straight, $10-20 \mathrm{~cm}$ in length and $1-3 \mathrm{~cm}$ in diameter. Upper and lower surface exhibit scars. Upper surface contains remnants of leaf bases. The rhizome is usually buff colored $10-30 \mathrm{~cm}$ in length and $1-3 \mathrm{~cm}$ in diameter. It does not have any characteristic odor or taste.

\section{Zingiber officinale}

Perennial herb with the erect stems about 1-2 m tall. Leaves are green, smooth, alternate, lanceolate in shape and is spirally arranged around the unbranched stem. The inflorescence is spike having bracteal flowers which are white to pink in color. The rhizomes are buff to yellow in color, fleshy about $10-15 \mathrm{~cm}$ in length and $1-3 \mathrm{~cm}$ in diameter. Rhizomes have a circular apical aperture and exhibit stiff hairs. They are laterally compressed and branched unlike that of Costus speciosus rhizome. The rhizome is usually buff to yellow colored, $10-15 \mathrm{~cm}$ in length and $1-3 \mathrm{~cm}$ in diameter. It has a spicy and aromatic odor and pungent taste.

\section{Microscopic character}

Costus speciosus: Rhizome showed periderm, the vascular bundle containing xylem, phloem, bundle sheath surrounded by fibers and parenchymatous ground tissue (fig. 1). The cortical region has several scattered vascular bundle (fig. 1-a). Periderm with stratified cork cells is also observed (fig. 1-b). The vascular bundles are crescent shaped consisting of sclerenchymatous fibers surrounding bundle sheath, xylem and phloem (fig. 1-c). T. S of rhizome showed thin walled collenchymatous, broken Epidermis with a tangentially elongated cell (fig. 1-d). L. S of the rhizome shows lignified fibers (fig. 1-e). When R. L. S of the rhizome was observed, parenchymatous ground tissue, lignified fibers followed by annular xylem vessels which are again accompanied by phloem, can be seen (fig. 1-f).

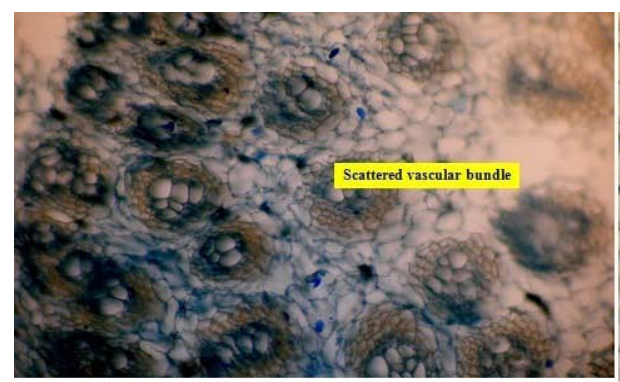

Cortical region of Costus speciosus rhizom

(a)

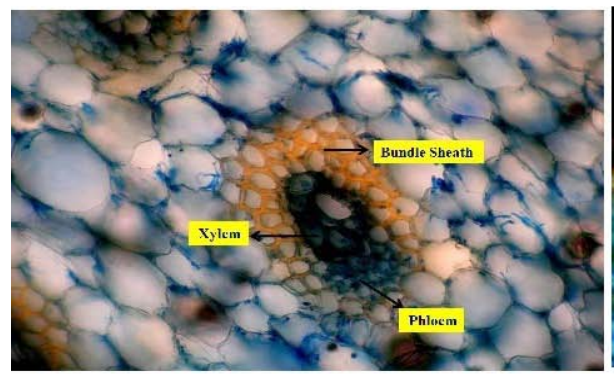

Magnified view of Vascular hundle

(c)

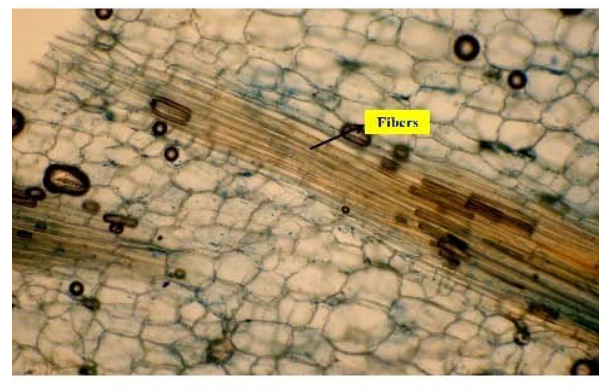

I.S of cosiux specion
(e)

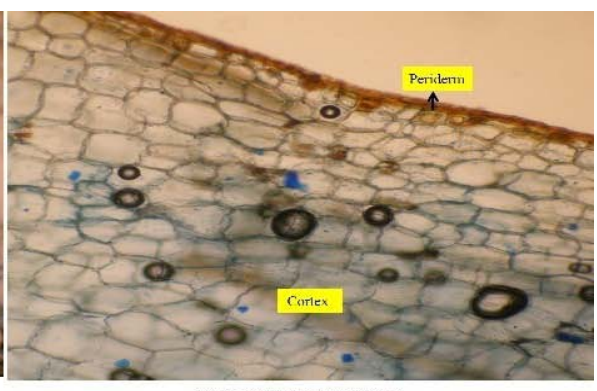

T.S of Coxtus speciosure Rhizame

(b)

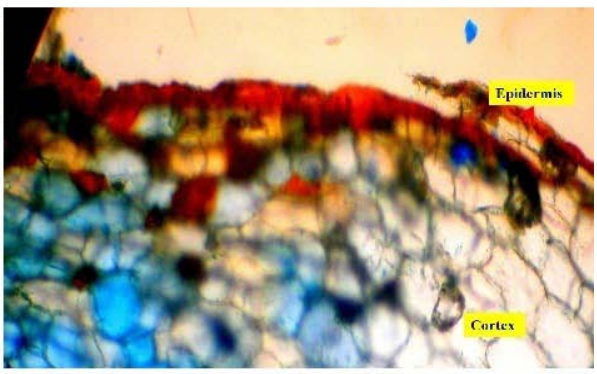

T.S of Costus specios

(f)

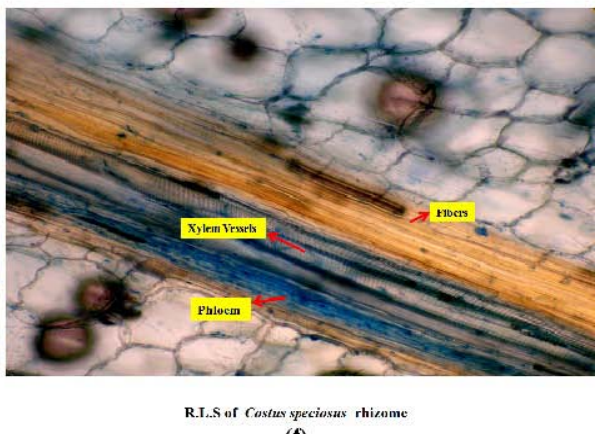

(f)

Fig. 1: Microscopic view of Costus speciosus Rhizome 


\section{Zingiber officinale}

Transverse section of rhizome showed outer and inner cork, parenchymatous ground tissue, endodermis, a vascular bundle containing xylem, phloem, fibers and oleoresin cell (fig. 2). T. S of rhizome shows outer black outer cork followed by colorless inner cork cell (fig. 2-a). It is followed by cortex containing thin-walled polygonal parenchymatous tissue and scattered conjoint, collateral vascular bundle containing xylem and phloem and surrounded by sclerenchymatous fiber (fig. 2-a, d, e, f). Tracheids and yellow polygonal oleo-resin cell are also present in the cortical region (fig. 2-b, c). Endodermis is single layered and a ring of vascular bundle is present below endodermis (fig. 2-d). L. S showed pitted fibers along with several rectangular oleo-resin cells (fig. 2 -f).

\section{Physicochemical studies}

\section{Costus speciosus}

The physicochemical parameters total ash value, acid insoluble ash value, water soluble ash value and moisture content which was determined to be not more than $4.25 \%, 1 \%, 2.5 \%, 3.3 \%$ respectively (table 2). The extractive values (ethanol, methanol, petroleum ether, chloroform, aqueous) which were determined to be not more than $4.14 \%, 6.8 \%, 2.64 \%, 1 \%$ and $6.34 \%$ respectively (table 3 ).

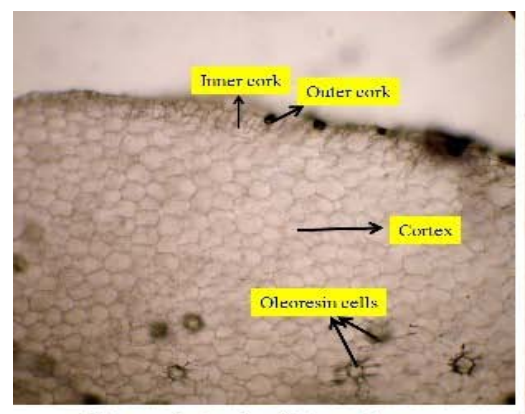

Outer cortical revion of ginger rhizame

(a)

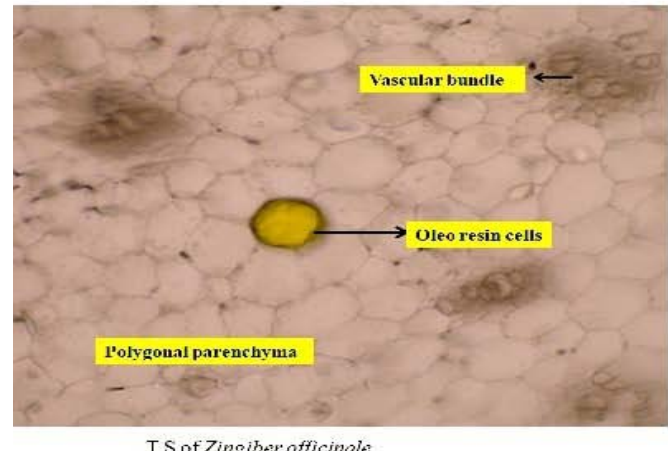

(c)

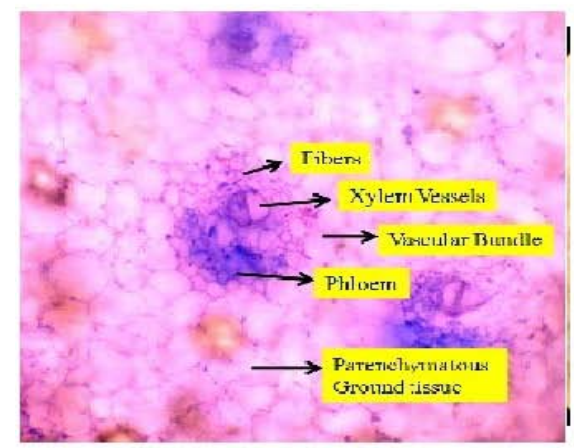

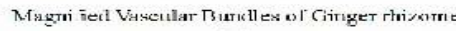

(e)

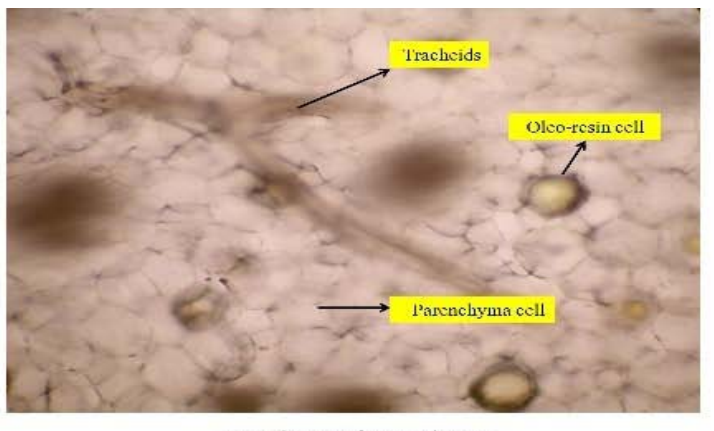

Cortical region of Ginger rhizomo

(b)

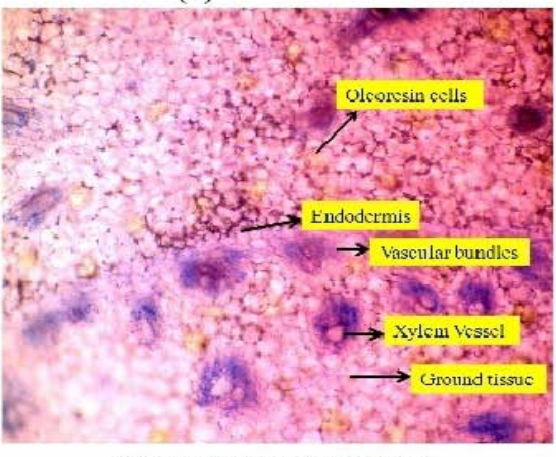

Iransverse section of Gingcr rhizome

(d)

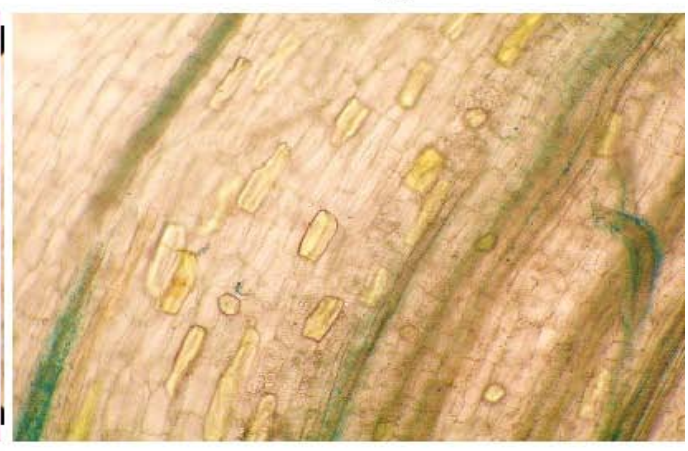

(f)

Fig. 2: Microscopic view of Zingiber officinale rhizome

Table 1: Microscopic differences between rhizome of Costus speciosus and Zingiber officinale

\begin{tabular}{lll}
\hline S. No. & Costus speciosus & Zingiber officinale \\
\hline 1 & Broken epidermis, Periderm containing storied cork. & The presence of black outer cork and colorless inner cork. \\
2 & Cortex containing lamellar parenchymatous ground tissue. & Cortex is containing polygonal, thin walled parenchymatous ground tissue. \\
3 & Vascular bundles surrounded by bundle sheath. & Vascular bundles are not surrounded by bundle sheath. \\
4 & Absence of oleo-resin cells. & The presence of oleoresin cells. \\
5 & Absence of tracheids. & The presence of tracheids. \\
6 & Absence of starch granules. & The presence of starch granules. \\
7 & Presence of lignified fibers & The presence of lignified pitted fibers. \\
8 & Endodermis is not prominent & Prominent endodermis followed by ring of vascular bundles \\
\hline
\end{tabular}




\section{Zingiber officinale}

The physicochemical parameters total ash value, acid insoluble ash value water soluble ash value and moisture content which was determined to be not more than $4.9 \%, 1.35 \%, 1.67 \%, 4.41$ respectively (table 2). The extractive values (ethanol, methanol, petroleum ether, chloroform, aqueous) which were determined to be not more than $4.0 \%, 7.79 \%, 1.8 \%, 1.2 \%$ and $10.8 \%$ respectively (table 3).

\section{Preliminary phytochemical investigation}

Preliminary phytochemical screenings were performed to find out the phytoconstituents (table 6).

Table 2: Ash value of Costus speciosus and Zingiber officinale rhizome

\begin{tabular}{llll}
\hline S. No. & Parameters & Values \% of Costus speciosus & Values \% of Zinziber officinale \\
\hline 1 & Total ash & 4.25 & 4.9 \\
2 & Acid insoluble ash & 1.0 & 1.35 \\
3 & Water soluble ash & 2.5 & 1.67 \\
4 & Moisture content & 3.3 & 4.41 \\
\hline
\end{tabular}

Table 3: Extractive value of Costus speciosus and Zingiber officinale

\begin{tabular}{|c|c|c|c|}
\hline S. No. & Solvent & Values \% (w/w) of Costus speciosus & Values\% (w/w) of Zinziber officinale \\
\hline 1 & Ethanol & 4.14 & 3.1 \\
\hline 2 & Methanol & 6.80 & 7.79 \\
\hline 2 & Petroleum ether & 2.64 & 1.8 \\
\hline 3 & Chloroform & 1 & 1.2 \\
\hline 4 & Aqueous & 6.34 & 10.8 \\
\hline
\end{tabular}

Table 5: Preliminary phytochemical screening of Costus speciosus and Zinziber officinale

\begin{tabular}{|c|c|c|c|}
\hline S. No. & Phytoconstituents & Hydroalcoholic extract of Costus speciosus & Hydroalcoholic extract of Zinziber officinale \\
\hline 1 & Alkaloid & - & + \\
\hline 2 & Glycoside & + & + \\
\hline 3 & Saponin & + & + \\
\hline 4 & Flavanoids & - & + \\
\hline 5 & Protein & - & + \\
\hline 6 & Tannins & - & - \\
\hline 7 & Carbohydrate & + & + \\
\hline 8 & Volatile oil & - & - \\
\hline 9 & Triterpenoid & - & + \\
\hline 10 & Steroidal nucleus & - & - \\
\hline
\end{tabular}

Fluorescence study was also performed (table 5 and 6 )

Table 5: Florescence study of Costus speciosus

\begin{tabular}{|c|c|c|c|c|}
\hline S. No. & Material treatment & $\begin{array}{l}\text { Observation under visible } \\
\text { light }\end{array}$ & $\begin{array}{l}\text { Observation under short UV at } 254 \\
\text { nm }\end{array}$ & $\begin{array}{l}\text { Observation under long UV at } \\
365 \mathrm{~nm}\end{array}$ \\
\hline 1 & Powder & Brown & Light green & Cream \\
\hline 2 & Powder+Conc. $\mathrm{HNO}_{3}$ & Brick red & Dark green & Black \\
\hline 3 & Powder $+\mathrm{NH}_{3}$ & Brown & Light brown & Green \\
\hline 4 & Powder+Dil. $\mathrm{HCl}$ & Brown & Green & Brown \\
\hline 5 & Powder+Conc. $\mathrm{HCl}$ & Dark brown & Black & Black \\
\hline 6 & Powder+1 $\mathrm{M} \mathrm{H}_{2} \mathrm{SO}_{4}$ & Brown & Light green & Light brown \\
\hline 7 & Powder+Picric acid & Light brown & Green & Cream color \\
\hline 8 & Powder+1M NaOH & Reddish brown & Dark green & Dark green \\
\hline 9 & Powder $+5 \%$ Iodine & Black & Black & Black \\
\hline 10 & Powder+KOH & Brown & Green & Dark brown \\
\hline 11 & Powder+Methanol & Brown & Green & Dark Brown \\
\hline 12 & Powder+Chloroform & Brown & Dark green & Light brown \\
\hline 13 & Powder+Ethanol & Dark brown & Green & Light brown \\
\hline
\end{tabular}

Table 6: Fluorescence study of Zingiber officinale

\begin{tabular}{|c|c|c|c|c|}
\hline $\begin{array}{l}\text { S. } \\
\text { No. }\end{array}$ & Material/treatment & $\begin{array}{l}\text { Observation under visible } \\
\text { light }\end{array}$ & $\begin{array}{l}\text { Observation under short UV at } 254 \\
\text { nm }\end{array}$ & $\begin{array}{l}\text { Observation under long UV at } 365 \\
\text { nm }\end{array}$ \\
\hline 1 & Powder & Off white & Light green & Cream \\
\hline 2 & Powder+Conc. $\mathrm{HNO}_{3}$ & Brown & Green & Dark brown \\
\hline 3 & Powder $+\mathrm{NH}_{3}$ & Brown & Green & Dark brown \\
\hline 4 & Powder+dil. $\mathrm{HCl}$ & Light brown & Green & Light brown \\
\hline 5 & Powder+Conc. $\mathrm{HCl}$ & Brown & Dark green & Dark brown \\
\hline 6 & Powder+1 $\mathrm{M} \mathrm{H}_{2} \mathrm{SO}_{4}$ & Light brown & Green & Creamish brown \\
\hline 7 & Powder+picric acid & Brown & Green & Dark brown \\
\hline 8 & Powder+1M NaOH & Dark brown & Dark green & Dark brown \\
\hline 9 & Powder $+5 \%$ iodine & Black & Black & Black \\
\hline 10 & Powder+KOH & Whitish & Brown & Dark brown \\
\hline 11 & Powder+Methanol & Brown & Light brown & White \\
\hline 12 & Powder+chloroform & Brown & Green & White \\
\hline 13 & Powder+ethanol & Reddish brown & Greenish & Dark brown \\
\hline 14 & Powder+FeCl 3 & Light brown & Light green & Dark brown \\
\hline
\end{tabular}




\section{DISCUSSION}

On the basis of the macroscopic study, we have found that there are some differences between both the plants. Leaves of Costus speciosus are elliptical in shape whereas that of Zingiber officinale is lanceolate in shape. The whole plant of Costus speciosus is slightly taller than that of Zingiber officinale. Flower of Costus speciosus is white in color whereas that of Zingiber officinale is white to pink in color. The rhizome of Costus speciosus is slightly longer and wider as compared to rhizome of Zingiber officinale. The most noticeable difference between Zingiber officinale and Costus speciosus is, the rhizome of Costus speciosus does not exhibit odor or taste whereas

The rhizome of Zingiber officinale exhibits spicy and aromatic odor and pungent taste.

Several characteristic differences are observed between Costus speciosus and Zingiber officinale on the basis of the microscopic study. The rhizome of Costus speciosus exhibit broken epidermis and periderm containing cork cell whereas Zingiber officinale rhizome exhibits outer black cork and inner transparent cork. Unlike Zingiber officinale rhizome, the vascular bundle of Costus speciosus rhizome is surrounded by bundle sheath. Also, unlike Costus speciosus rhizome, Zingiber officinale rhizome is characterized by the presence of an oleoresin cell, tracheids and starch granules and prominent thin-walled endodermis

Total ash value of Costus speciosus rhizome and Zingiber officinale rhizome indicates that Zingiber officinale rhizome contains more amount of inorganic radical as compared to Costus speciosus rhizome since it is lower in the case of Costus speciosus rhizome when compared with Zingiber officinale rhizome. Similarly, acid insoluble ash value of Costus speciosus rhizome is lower than Zingiber officinale rhizome indicating the higher content of silica and oxalates in Zingiber officinale than Costus speciosus. The water soluble ash value of Zingiber officinale is lower than Costus speciosus rhizome again indicating the higher amount of foreign material in Zingiber officinale as compared to Costus speciosus since foreign material causes lowering of water soluble ash value. Moisture content of Zingiber officinale rhizome is higher than that of Costus speciosus rhizome

The phytochemical profiling of Costus speciosus revealed the presence of saponin, carbohydrate glycosides. Fluorescence analysis of the drug powder was carried out. Whereas that of Zingiber officinale revealed the presence of alkaloids, glycosides, saponins, flavonoids, protein, carbohydrates and Triterpenoid.

\section{CONCLUSION}

The comparatives pharmacognostic standards for the Costus speciosus and Zingiber officinale are laid down for the first time in this study. Costus speciosus and Zingiber officinale are used for the treatment of the various medical condition. But, the benefits can only be enjoyed if the pure quality of drug is used, therefore, standardization of the particular plant is the initial step before the establishment of plant's pharmacological activity. Morphological and anatomical studies of plant parts will enable to identify the crude drug. The information obtained from the preliminary phytochemical screening will be useful in finding out the ingenuity of the drug. Ash values, extractive values can be used as a reliable aid for detecting adulteration. Moreover, there are certain plants that are somewhat similar to each other, therefore, the comparative study can be undertaken to observe the characteristic differentiating features. Further study should be carried out in future to isolate the specific chemical constituents as well as the detailed pharmacological activity in the proper scientific way.

\section{CONFLICT OF INTERESTS}

Declare none

\section{REFERENCES}

1. Srivastava S, Singh P, Mishra G, Jha KK, Khosa RL. Costus speciosus (Keukand): a review. Der Pharm Sin 2011;2:118-28.

2. Rani AS, Sulakshana G, Patnaik S. Costus speciosus, an antidiabetic plant-review. FS J Pharm Res 2012;1:52-3.

3. Gupta AK, Tondon N, Sharma M. Quality standards of Indian medicinal plants, Medicinal Plants Unit. Published by Indian Council of Medical Research. (VII); 2008. p. 48.

4. Eliza J, Daisy P, Ignacimuthu S. Influence of Costus speciosus (Koen.) Sm. rhizome extracts on biochemical parameters in streptozotocininduced diabetic rats. J Health Sci 2008;54:675-81.

5. Aziz S, Hassan SMM, Nandi S, Naher S, Roy SK, Sarkar PR, et al. Comparative studies on physicochemical properties and GC-MS analysis of essential oil of the two varieties of ginger (Zingiber officinale). Int J Pharm Phytopharm Res 2012;1:367-70.

6. Sultan M, Bhatti HN, Iqbal Z. Chemical analysis of essential oil of ginger (Zingiber officinale). Pak J Biol Sci 2005;8:1576-8.

7. Cutler DF, Botha CEJ, Stevenson DW. Plant anatomy: an applied approach, Blackwell Publishing ltd U.S.A; 2007. p. 170-94.

8. Ray FE. Esau's plant anatomy: meristems cells and tissues of plant body: their structure, function, and development. 3rd edition. John Wily, Sons, Inc, Hoboken, Editors, New Jersey (USA); 2006. p. 194-8.

9. Chaudhary S, Khosa RL, Ali SS, Kumar S. A report on pharmacognostical and quality control parameters of stem and root of Leptadenia pyrotechnica (forsk) decne. J Pharm Res 2012;5:604-9.

10. Khandelwal KR. Practical pharmacognosy techniques and experiments. Nirali Prakashan Pune; 2002, p. 149-56.

11. Kokate CK. Practical pharmacognosy. $4^{\text {th }}$ edition. Vallabh Prakashan, Delhi; 2005. p. 108-9.

\section{How to cite this article}

- Chandra Kala, Syed Salman Ali, Sudhir Chaudhary. Comparative pharmacognostical evaluation of Costus speciosus (Wild ginger) and Zingiber officinale (ginger) rhizome. Int J Curr Pharm Res 2016;8(4):19-23. 